\title{
TRACING CULTURAL LANDSCAPE VALUES OF CHILDREN WITH PARTICIPATORY GEOGRAPHIC INFORMATION SYSTEM
}

\author{
Laura Puolamäki ${ }^{1}$
}

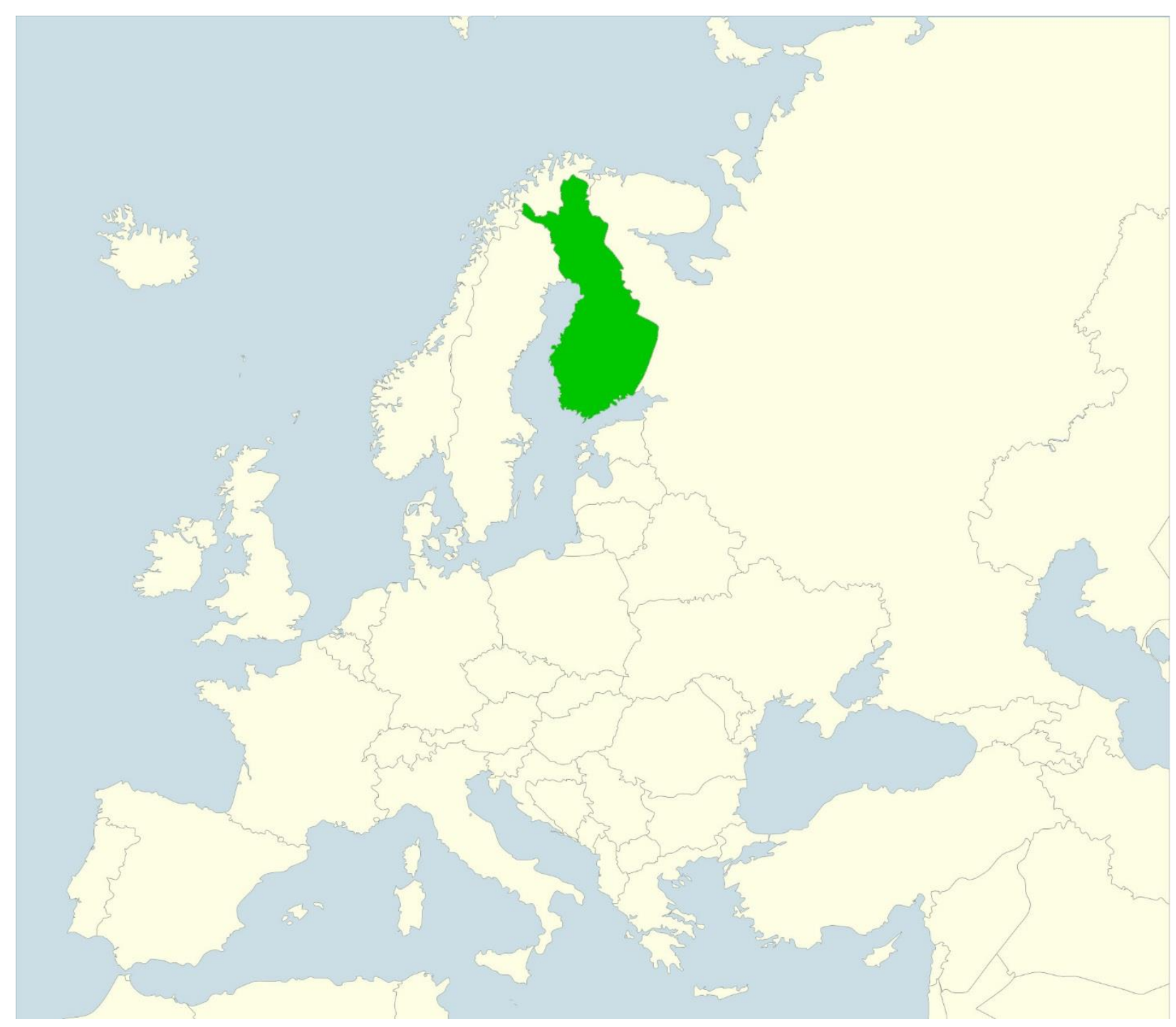

\footnotetext{
${ }^{1}$ Laura Puolamäki, MA, PhD student, University of Turku, Degree Program in Cultural Production and Landscape Studies; Project manager, Rauma Town, City Planning Department, Peltovaarantie 6, Finland, FIN-27420 Panelia as Phone +358 44 0617222; e-mail: Ilpuol@utu.fi
} 
Abstract: The cultural landscape value categories found from the workshop evaluation describe the character of the cultural landscape of children: living, learning and moving in the network of places between home and the world outside based on the local and family culture creates both individually and collectively valuable places. When these places are situated in a listed building or landscape area, the cultural landscape values of expert evaluation and children's evaluation connect. But based on this case study these value objects are more often disconnected. Landscape evaluation produced with children by suitable methods reveal the network of places and ways to experience them. Experience is a key for opening cultural heritage to this group. By finding a way to afford the experience they desire in the places of listed heritage, children could connect better to cultural landscape.

Key words: cultural landscape, cultural heritage, landscape values, European Landscape Convention

Tiivistelmä: Työpajoissa saatujen tulosten analyysin pohjalta tehty luokittelu kuvaa lasten kulttuurimaisemaa: Asuminen, oppiminen ja liikkuminen kulttuurimaisemassa sijaitsevien paikkojen verkostossa synnyttää yksilöllisesti ja yhteisöllisesti arvokkaita kohteita. Niiden valikoituminen riippuu sekä lapsen oman perheen että paikallisyhteisön toimintakulttuurista. Kun arvokkaat paikat osuvat johonkin suojelukohteeseen tai -alueelle, kulttuuriympäristön asiantuntijoiden ja lasten maisema-arvot kohtaavat. Tämän tapaustutkimuksen tulosten perusteella se tapahtuu kuitenkin harvoin. Lasten kanssa työskentelyyn soveltuvilla menetelmillä tuotettu kulttuurimaiseman arvottaminen tuo esille heille arvokkaiden paikkojen verkoston sekä tavat kokea ne. Kokemuksen kautta voidaan avata kulttuuriperintö lapsille. Soveltamalla lasten tapaa tutustua kulttuuriympäristöönsä kokemuksen kautta myös suojelluissa kohteissa voitaisiin tarjota tällekin ikäryhmälle mahdollisuus liittää ne osaksi omaa paikkaidentiteettiään.

Avainsanat: kulttuurimaisema, kulttuuriperintö, maisema-arvot, Eurooppalainen maisemayleissopimus

\section{Introduction}

With this study I wanted to see where children's values are attached in the cultural landscape of Satakunta region, how they can be revealed, how they connect with expert values and how combining these diverse perspectives could contribute to preservation when evaluation process respects the definition of landscape of the European Landscape Convention (ELC, CoE 2006).

Cultural landscape inventories often focus on mapping and evaluating listed heritage or nature values. Sometimes the scope is widened into the landscape level, and local people are consulted about their landscape values. In those cases we intend to stay within our own reference group, adults. Children are considered as users of landscape or objects of education, not so much as equal evaluators of landscape with their special understanding about it.

Working together with children requires careful research design in order to respect their way to perceive and evaluate landscape, as well as their way to express their knowledge and opinions about it.

Roger Hart (1979) noted in his study about the children of Inavale, USA, that

"many aspects of the experience of place cannot be discovered by geographical or psychological methods nor in fact by any formal procedure. We must recall it ourselves or rediscover it through empathy with children...In this way we can approach the description of 
experience rather than the usual causality-bound accounts of environmental behavior; the problem lies in finding the words!"

Environmental psychologist like Gibson, Brofenbrenner and Kyttä have studied the interaction between the children and their environment based on the concept of the environment and the humans as a whole (Brofenbrenner 1979, Kyttä 1997, 2002, 2003, 2004; Korpela et al. 2002).

Brofenbrenner defines ecological human development

as the person's evolving conception of the ecological environment, and his relation to it, as well as the person's growing capacity to discover, sustain or alter its properties (Brofenbrenner 1979).

This evolutionary process reshapes children's cultural landscape values. They are found in places, where children are allowed to go, to spend time and to get familiar with. Such places change along with the process of growth. Therefore, children's criteria for defining the landscape values is not stabile or general, but individual and ever changing. The affordances of the environment and the freedom of mobility of an individual child affect children's interaction with their cultural landscape. Children perceive the affordances for action in the landscape, utilize them and shape afforded landscape for their needs (Kyttä 1997, 2002). Children's perceptions about the cultural landscape are also learning about the landscape while developing the environmental competence skills (Pedersen, 1999, Krogh et al. 2008). Such a learning produces knowledge, which is based on experiences and intuitive associations (Haapala 2000, Syse 2006, Puolamäki 2012).

The environmental knowledge of children also has elements of knowledge, which is called practical knowledge, when it considers adults. When Hart (1979) found problem in finding the words for describing the children's experience gained from the environment of Inavale, Syse (2006) found somewhat similar problems between the farmers and experts in describing the local knowledge of the landscape in Argyll, Scotland. She argues, that practical knowledge is represented and codified in a way uncongenial to science, and therefore challenging to include into scientific or expert documentation. Perhaps this is one of the reasons why children's landscape values are often lacking from evaluation data.

When data is produced with children, research ethics needs to be considered carefully. Starting point for this consideration could be the UN Convention on the Rights of the Child (1989). The convention defines the children's rights as the right to be treated by their best interest (article 3 ), the right to get their views respected (article 12-13) and the right to be protected from exploitation (article 36).

Victoria Morrow (2008) has discussed in her article Ethical dilemmas in research with children and young people about their social environments about the research ethics and conceptualizing childhood in such a research. She argues, that the choice of the theoretical standpoint of understanding children influences the research population studied, the methods used and crucially the interpretation of the data collected. The social child model, which is applied here, envisages children as research subjects comparable with adults but possessing different competencies. Based on the UN Convention on the Rights of the Child, the research strategy needs to be designed on the capacities and mediums children are skilled and confident to use. Such capacities and skills are written works, drawing, photographing and interpreting their work with speech. Using these talents that children possess allows them to engage more productively to the research (Morrow 2008). It also strengthens possibilities to discover, which are the things that matter to children in the landscape and how they are connected.

When landscape is defined "as an area as perceived by people", landscape is extended from material objects to an expression of interrelations between people and their material surroundings (CoE 2006, Jones, Howard, Olwig, Primdahl \& Herlin 2007). Cultural landscape includes also immaterial, perception-based dimensions (Wylie, 2007; Plieninger et al, 2015).

Cultural landscape with its material and immaterial dimensions shape people's sensibility, language, beliefs and way of thinking; forms of land use, technology, housing and social organization are adapted to these particular conditions. 
Landscape preferences have a strong relationship to perception and place attachment. The landscape preference studies in Røros, Southern Norway (Kaltenborn \& Bjerke 2010) showed, that the more familiar and personal a landscape is to a person, the more preferable it becomes, when landscape is evaluated. Landscape values preferred by children are also assumed to be found in places with which they have been familiarized.

In the recent years, there have been many studies about the landscape values of the local adult people. Libby Robin (2012) has argued

"for a broader spectrum of expertise in framing a collective "authority" to speak for managing places of natural significance"

This argument is essential also for evaluating cultural landscapes. Defining rational goals from shared values, including both expert and practical knowledge (Yli-Pelkonen et al. 2005, Selman 2006, Syse 2006, Brunetta \& Voghera 2008, Jones \& Stenseke: 2011, Bieling and Plieninger 2012, Selman 2012, Robin 2012) in the cultural landscape evaluation is a process where science and intuition as well as authorized expertise and practical expertise can be merged.

Paul Selman (2012) argues for reconnection of the cultural landscapes in order to enhance sustainability. Connecting functions in the cultural landscape is balancing between the cultural heritage and dynamic drivers for change. Selman also argues for reconnection of the cultural landscape elements and factors in order to create resilient cultural landscapes. According to Selman a key argument for landscape reconnection is that a landscape in which functionality is widely restored is likely to be more resilient, and less vulnerable for future shocks. Resilient cultural landscape is able to change, reorganize and yet keep its identity.

According to Selman (2012)

Building of social resilience challenges stabilized knowledge, in which the preferred solutions are explained to people in order to fill their knowledge deficit. Instead it requires joint knowledge development and negotiation between values. The negotiated result at its best could be a landscape of shared values, a source of cultural identity and a reserve of cultural heritage.

Children engage with cultural landscape through functions. The places where their functions emerge are connected with safety and age; some places are to be explored with family, some to be explored freely. Therefore children's attachment to cultural landscape intertwines significantly with mundane environment and settings of commerce, sports, education and home. Connections with culture and nature are more dependent on personal livelihood and family values. Activities in the landscape shift from play and adventure to hanging and grouping as childhood turns into teenage. These activities are practised in places where children and youth are allowed to go; school yards, malls, shop windows, streets, playgrounds, sport arenas.

The cultural landscape values are often defined in expert documentation from material objects rather than from immaterial activities practised around those objects. Among children and youth the cultural landscape values stem from the use, and the knowledge is related to dynamics and connections between landscape objects. These values cannot be traced with inventory methods for physical landscape elements - they need to be discovered by describing the experience with the methods possessed with this group and the unstabilized nature of these values needs to be accepted.

In the previous paragraphs, there was introduced an individual and human-based approach for recognizing cultural landscape values was introduced. This approach needs to be completed with international and national criteria for defining the landscape values (UNESCO 1972, 2003; CoE Granada 1985, Malta 1992, Firenze 2000, Faro 2005, ELC 2006) in order to evaluate cultural landscape also through currently used expert framework. This criteria is general and based on mutual agreement, and revised in long cycle. Within this criteria, the cultural landscape is evaluated as locally, regionally, nationally or internationally valued based on the rationalized steering documents at the European level or based on the World Heritage Convention.

This framework evaluates landscape depth and connectivity through temporal layers in itself. It does not consider peoples' different perceptions of landscape or connections to landscape 
depending on their age. To discover them, we need to expand the evaluation toolkit. The following chapters present one case study where children's skills, perceptions, knowledge and maps were combined in order to trace their landscape values in Satakunta Region, Finland.

\section{Method}

\section{Participative mapping}

The objective of the workshops was to enable children to express their local cultural landscape knowledge and values and present it in a way suitable for cultural landscape evaluation and planning.

UNESCO has adapted cultural mapping methods for illustrating the linkages between indigenous people and their land. Tenure maps show local names, traditional resources, seasonal movements and activities and special places. Of tenure mapping methodologies, the placing of local information directly on topographic maps is very close to the method used in this case study (Poole 2003).

Cultural mapping methods are also used for exploring and visualizing intangible elements like networks, links and patterns of usage of the landscape in the cities and other cultural landscapes (Crawhill 2007, Stewart 2007, Bianchini \& Ghilardi 2007, Duxbury \& Jeannotte 2015).

The need for including practical knowledge into the scientific discourse has created applications of Geographic Information System (GIS) and participatory mapping. With PGIS, the understanding of the complexity of material and immaterial values of landscape can be visualized, and the connections between values, landscape patterns, landscape dynamics and cultural heritage can be understood (Mikusinski, Blicharka, Antonson, Henningson, Göransson, Angelstam \& Seiler 2012).

Brown \& Reed (2012) coin their method as Public Participation Geographic Information System, PPGIS. Brown \& Reed defined PPGIS as a tool for combining the academic practice of GIS and mapping at local levels to produce knowledge of a place as social landscape metrics. Social landscape metrics measure the structure and patterns of human perceptions of landscape.

Käyhkö, Fagerholm et al. have applied participative GIS methods in the mapping campaigns in Zanzibar, Tanzania (Käyhkö \& Fagerholm, 2009, Fagerholm et al. 2012). When Brown \& Reed studied landscape values as spatial data in public internet-based GIS, Käyhkö et al. collected social values associated with various places. They collected spatial data from individuals by mapping the places on orthophotoimage, compiled the data with interviews and processed the participatory mapping and manual field notes into digital form. In the second phase, the results were introduced to the local people in an open meeting, in order to verify the interpretation of the earlier collected data.

The participative individuals were a sample of desired population group, selected for example from the basis of age (15-30 years, over 31 years). The platform for mapping was an orthophotoimage in order to afford a readable medium for all the participants, because the mapping skills were found to be limited. However, the research in Zanzibar excluded children, while in this study, the focus was solely on children and youth.

Swensen et al (2012) used a method, which they coined, the mall method. They approached people in their everyday environments, malls, and firstly, they triggered the interview with photos of well recognizable local heritage objects and photos of objects from more recent decades to avoid steering the informants' thoughts towards an "acceptable cultural heritage". Secondly, the informants were asked to map the cultural heritage objects valuable by themselves individually. The maps were printed, and therefore in need for further processing in order to compare the field results with the results from official's landscape evaluation carried out earlier.

\section{The workshops}

In this study, the primary research material was collected from the cultural landscape workshops, which were held during the school hours in four municipalities (Eura, Luvia, Ulvila, Rauma) at six 
different schools. The method was designed to afford the children such tools they are trained to use to express their opinions, and to produce such forms of data the experts are trained to evaluate. It also included the elements of earlier mentioned mall method, by introducing the concept of cultural landscape with photographs of recognizable national object and more surprising local objects.

In the workshops, the individual task of each child was to write about his cultural landscape values. The confidence of the map reading skills and the verification of the accuracy of the reported points was covered by entering the texts in a joint task of the class on the web-based GIS projected to the wall in the classroom, and by discussing about the choices at the same time. Some places may be cumulative, if they were valuable to many participants. Reporting the values on the map in front of the class via data projector, directly to the GIS platform, was an objective to build confidence in children towards the project and the respect of their opinion. Another objective was to avoid errors when moving pin-pointed objects from paper map to digital map after the workshops. The third objective was to create digital data which could be shared directly to expert participants.

The writing task was triggered with photo slide presentation of cultural landscapes in random areas, but not from Satakunta region in order to avoid leading with recognizable examples. After the presentation, the following individual writing task was given:

Tell me about your valuable cultural landscape in your home village or area! Where is it? Why do you find it important?

Because the objective was also to reflect children's values to the inventory values, the platform of digital map was chosen. The reported places or areas were mapped to the web-based GISapplication called PaikkaOppi (Regional Council of Southwest Finland; www.paikkaoppi.fi) in all the workshops except the last two. At the time of the last workshops, the PaikkaOppi service was temporarily out of use, and it was replaced with Google Maps.

Children introduced their arguments and the situation of their choice of places to the class when they were put on the map after the writing task. Their places were discussed together with other children during the introduction. This was highly necessary in order to clarify to an outside observer, the researcher, why these places were chosen. The writings were also entered as an attribute to the GIS.

The workshops were documented on research diary with immediate reflections and comments for the following workshops.

Expert cultural landscape evaluation is based on Land Use and Building Act (132/1999) and it usually precedes land use planning process. Cultural landscape evaluation in local level is framed with Land Use and Building Act, but also with Built Heritage Act (4.6.2010/498) and Antiquities Act. (295/1963). National inventories of built heritage (RKY, National Bureau of Antiquities 2009) and valuable rural landscape areas (Arvokkaat maisema-alueet, Ministry of the Environment 2016) are also a part of this framework. In special cases, like in Rauma, World Heritage Convention is naturally included as a steering document. Evaluation begins with expert inventories of the planning area of cultural landscape, built heritage and antiquities with before mentioned framework. Inventory results are assessed by architectural values, archaeological values, landscape depth, landscape integrity and authenticity. Sometimes local people are interviewed when inventory concerns private property, like houses, in order to map more detailed information about the changes in appearance or use.

In the areas of this case study, National inventories of built heritage (RKY, National Bureau of Antiquities 2009) are affected in three municipalities: Panelia village in Eura, medieval church and road in Ulvila and some areas in Rauma Town. The center of Rauma Town is also a World Heritage Site, Old Rauma. In Panelia village there are hundreds of archaeological sites from Bronze Age. Old Rauma World Heritage Site is an archaeological site as a whole. All the areas have some protected buildings according to Built Heritage Act. 
After each workshop a weblink to the results was sent to a volunteer expert. Experts were people who have been professionally involved in cultural landscape and built heritage inventories in the area.

Experts analyzed the results and compared them to their own data and evaluation. Experts were also asked to introduce some heritage objects which were not pin pointed at the workshops but were highly interesting from the expert's point of view.

In the second workshop visit the comments of the volunteer expert were presented to the class by the researcher. Experts took their task very seriously and wrote respective notes about children's evaluation.

After presentation, the class was taken to a field trip to explore the heritage object which the expert had chosen. If places from children's choices were on the way, they were also checked and discussed.

\section{Research}

\section{The area}

The region of Satakunta is located at the west coast of Finland. The administrative municipality of the region is Pori, a city of 78,000 inhabitants. Outside Pori, there are 20 minor municipalities. The second biggest town, in which the two World Heritage sites of the region are located, is Rauma with 37,000 inhabitants.

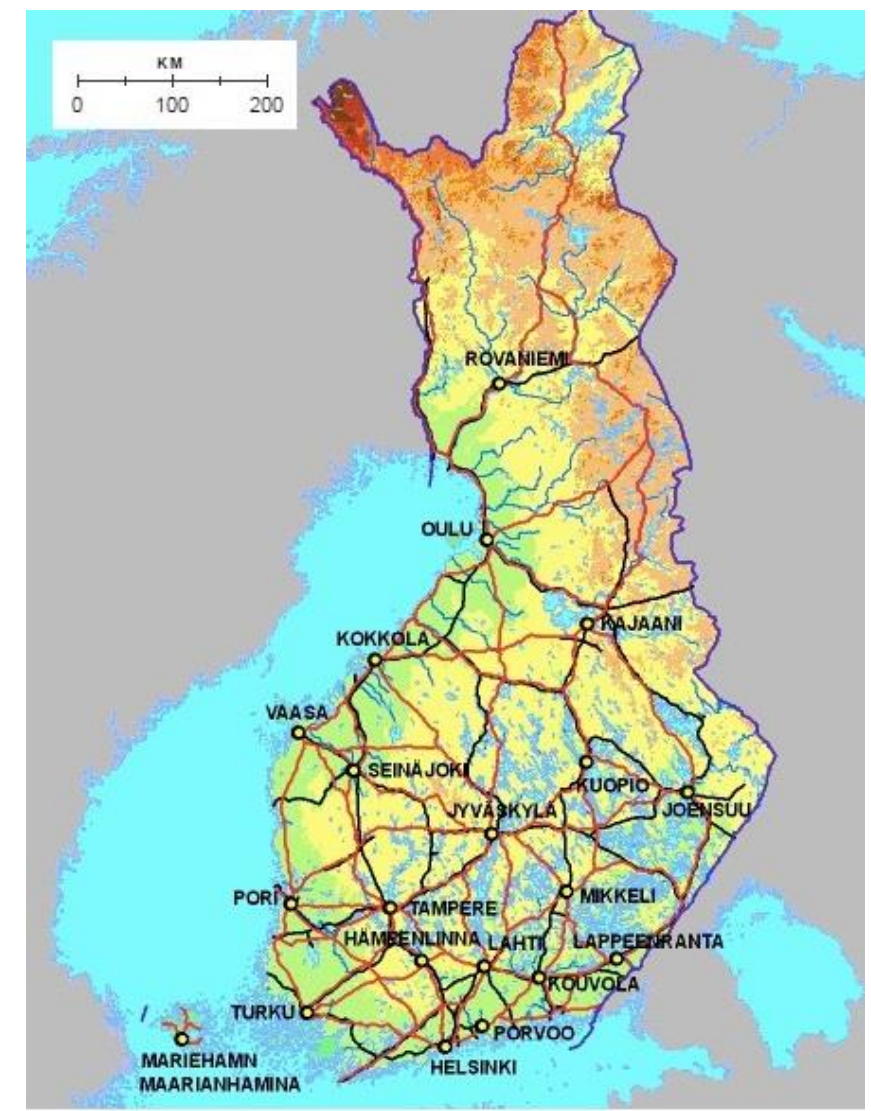

Fig 1. Map of Finland. Source: Paikkaoppi.fi

The schools for the cultural landscape workshops were selected on voluntary basis. The invitation to participate in a workshop was sent to the schools, which are situated close to the some of the valuable cultural landscapes of the Satakunta region (Satakuntalaiset kulttuuriympäristöt 2007). These areas have already been officially evaluated (Satakunta museum, inventory database Pakki). The cultural landscape workshops were held at Kaasmarkku and Friitala villages 
in Ulvila municipality, Panelia village in Eura municipality, at the junior high school in the center of the Luvia municipality and at 2 schools in Rauma, situated close to the World Heritage site. Workshops involved 165 pupils between ten and fourteen years of age. The workshops were held during the autumn of 2011, the spring of 2012, the autumn of 2014 and the spring of 2015.

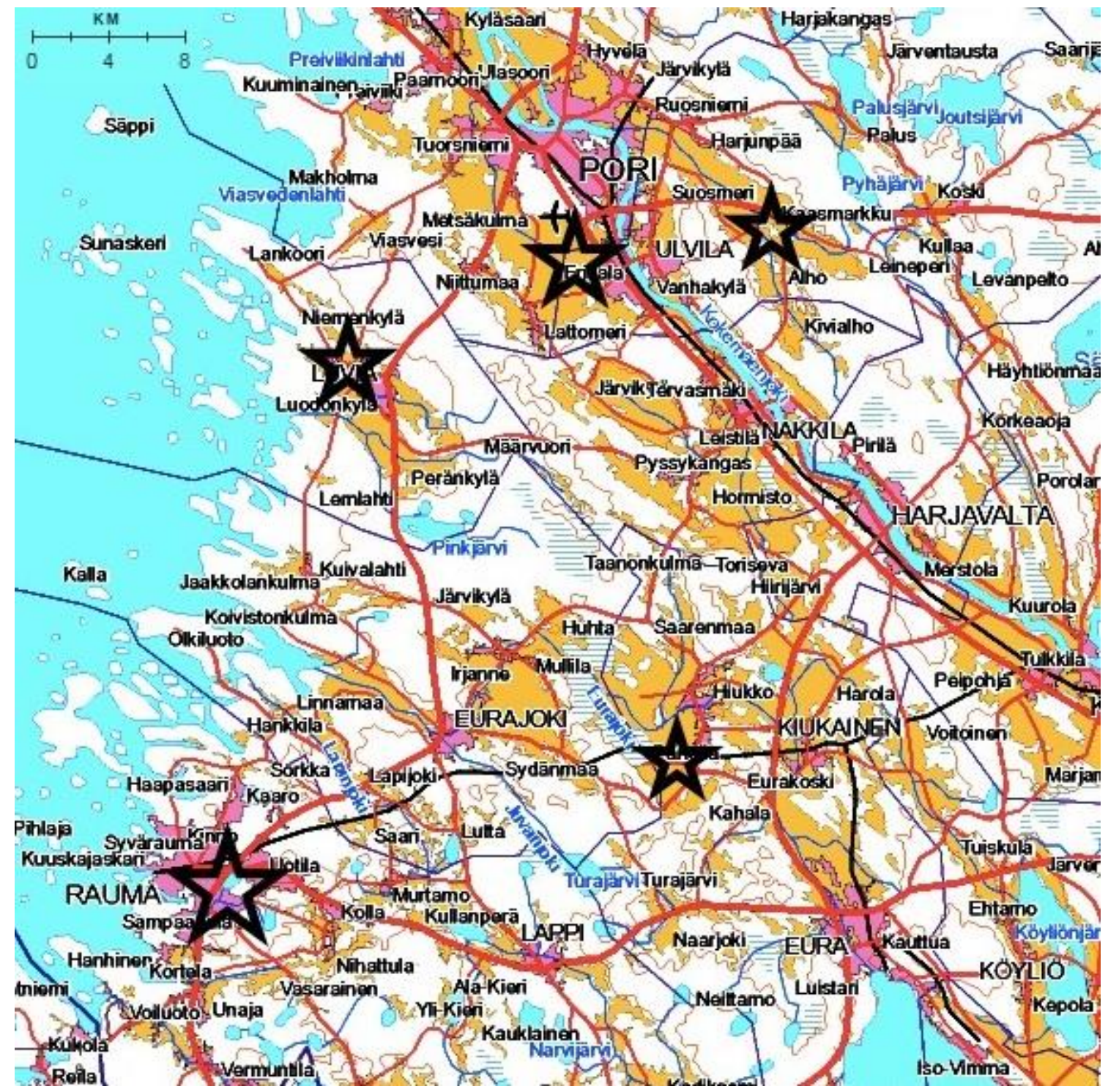

Fig 2. Research area. Source: Paikkaoppi.fi, modified by Puolamäki, L.

Small and compact countryside village Kaasmarkku belongs to Ulvila municipality. It has wellpreserved cultural layers beginning from $16^{\text {th }}$ century. Industrial heritage is a distinctive feature, although there is no industrial activity left. The village school is very well orientated to local cultural heritage, and lessons are taken out to the landscape on regular basis. Ulvila municipality is a medieval center of the region upstream by the river Kokemäenjoki. Due to the land uplift the river became too shallow to sail to Ulvila, and the town was re-established downstream to Pori in the $16^{\text {th }}$ century. The stone church on the opposite side of the river than Friitala village is from the 13th century (Salo 2008: 290-303). Friitala is at the urban fringe of Pori, only $10 \mathrm{~km}$ away from the current city center. Luvia is a village at the coast of the Bothnian Sea, between the cities of Pori and Rauma. It has a population of 3,300 people. The village center was established at the shore, but the land uplift has moved the sea kilometers away. The wide field expanse by the village center is a former bottom of the sea, and it was drained in the $19^{\text {th }}$ century in order to increase the cultivation land. The expanse is a nationally valuable cultural landscape (Ministry of the Environment 1992: Important Landscape Areas). 
Panelia is an inland village with valuable archeological sites of 1,300 inhabitants in the rural inland municipality of Eura. The small but lively community with long traditions of dwelling is situated relatively far from the municipality center. The village was established in the Bronze Age to the bottom of an ancient bay, to which the river Eurajoki runs to through the rapids of Paneliankoski. The largest Bronze age mound in the Nordic countries stands by the village road. In the listing of the villages in Satakunta from the year 1560 Panelia was the largest village with 20 houses (Salo 2001, 2008: 90-111).

Situated on the Gulf of Botnia, Rauma is one of the oldest harbors in Finland. Built around a Franciscan monastery, where the mid-15th-century Holy Cross Church still stands, it is an outstanding example of an old Nordic city constructed in wood. Although ravaged by fire in the late 17th century, it has preserved its ancient vernacular architectural heritage. Old Rauma was inscribed as a World Heritage site in 1991.

\section{Results}

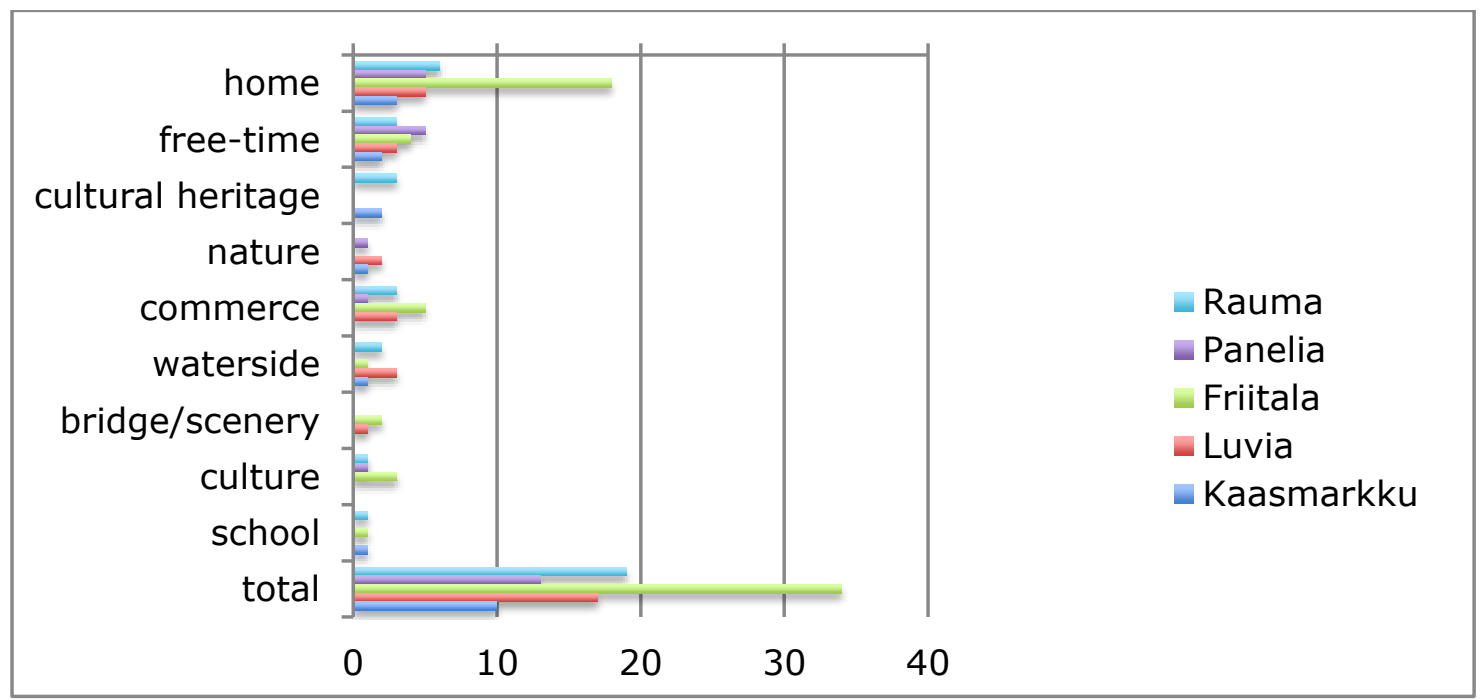

Fig 3. The cultural landscape value categories.

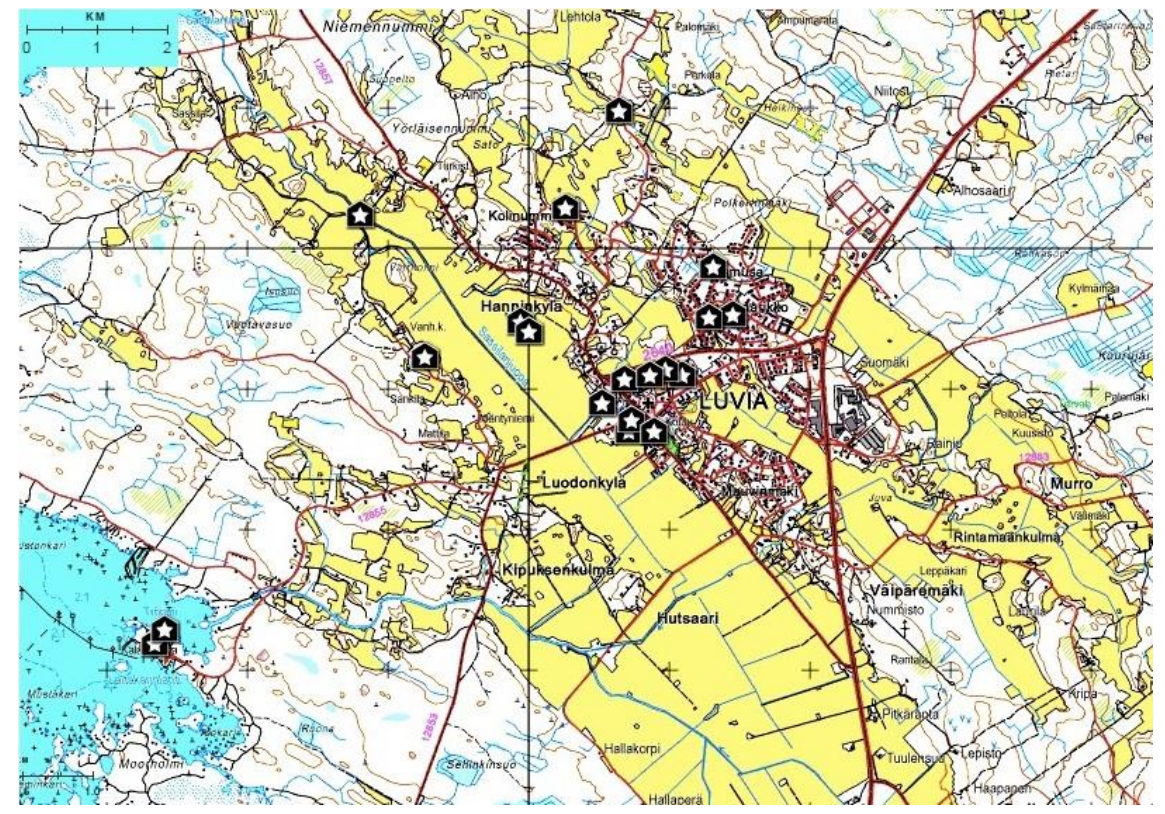

Fig 4. Map presenting the places or objects which were pin-pointed in the workshops at Luvia school. Source: PaikkaOppi 
The cultural landscape value categories found from the workshop evaluation describe the character of the cultural landscape of children: living, learning and moving in the network of places between home and the world outside, based on the local and family culture it creates individually and collectively as valuable places. The places children evaluate as important and worth preserving are often outside those areas that experts have chosen. Children's landscape values are based on landscape experience. They don't just look at the landscape, but touch, imagine, feel and use it.

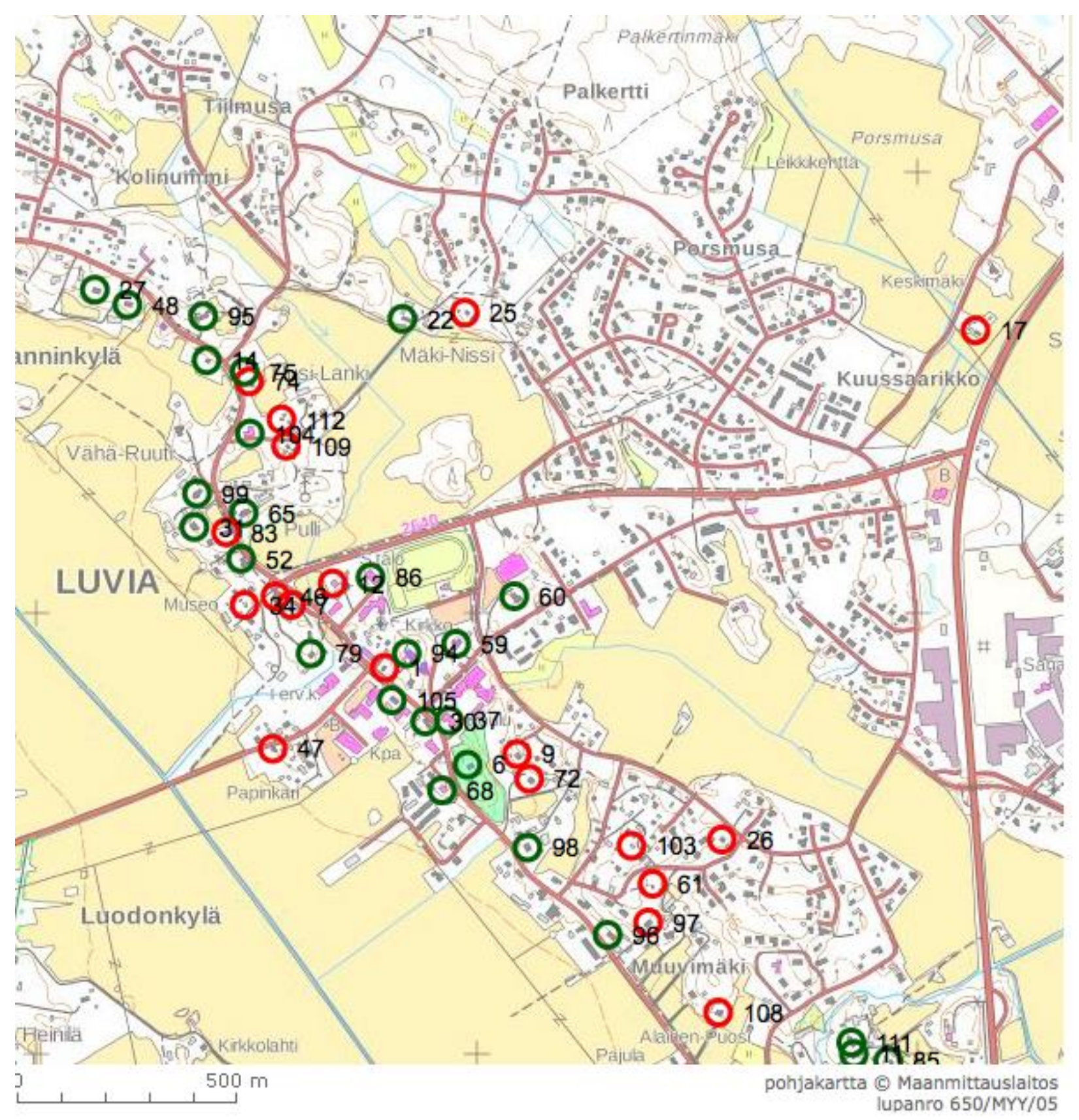

Fig 5. Map presenting the objects which were evaluated during the built heritage inventory in Luvia 2008 by Satakunta Museum. Source: Pakki inventory database

As these maps illustrate, places or objects of value seem to overlap, but when the map is viewed closer, they separate. Children do not pin-point objects found with cultural heritage value framework, unless those objects are their homes, places of free time or related to some other activity. 


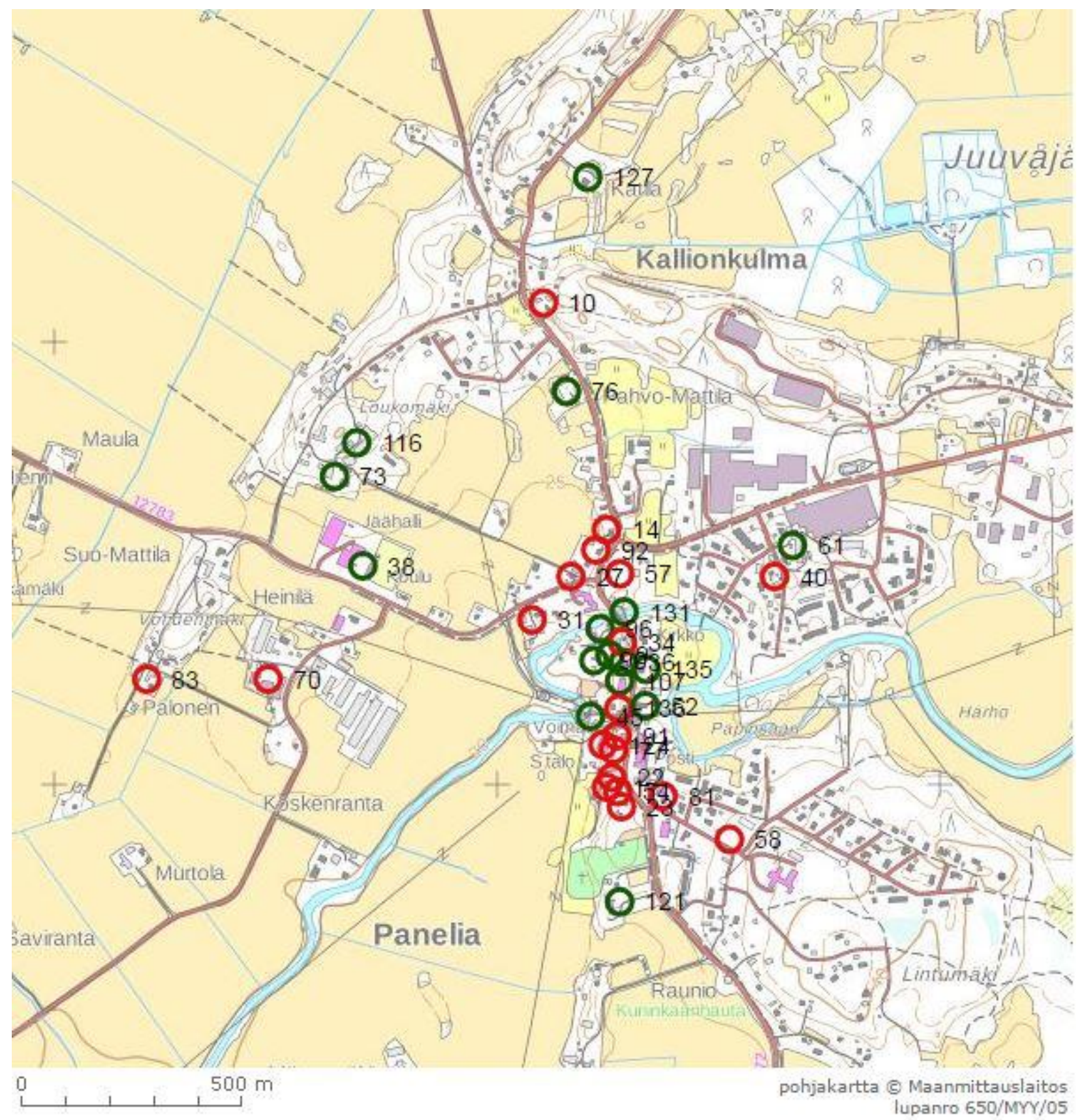

Fig 6. Map presenting the objects which were evaluated during the built heritage inventory in Panelia village 2012 by Satakunta Museum. Source: Pakki inventory database 


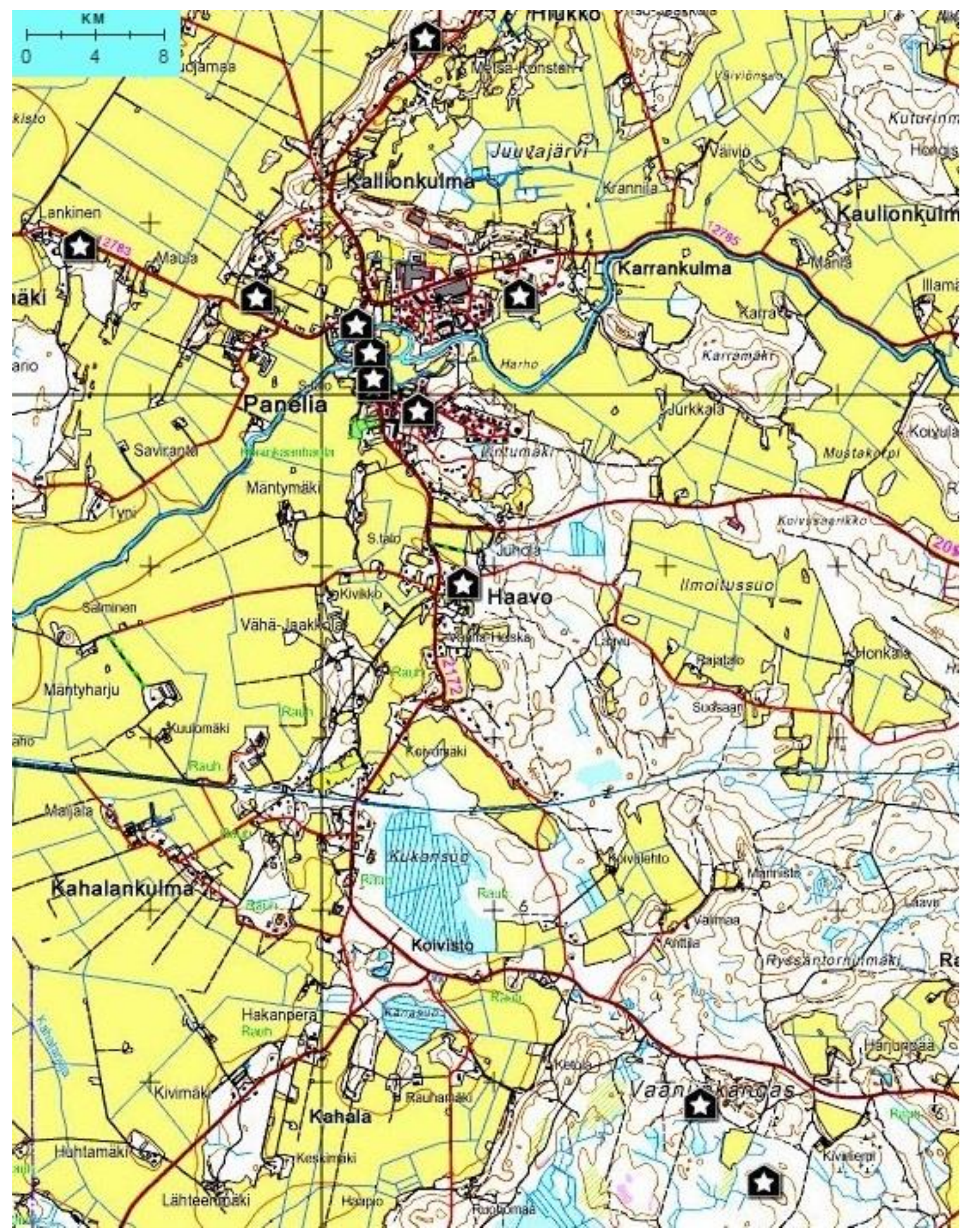

Fig 7. Map presenting the places or objects which were pin-pointed in the workshops at Panelia school. Source: PaikkaOppi 


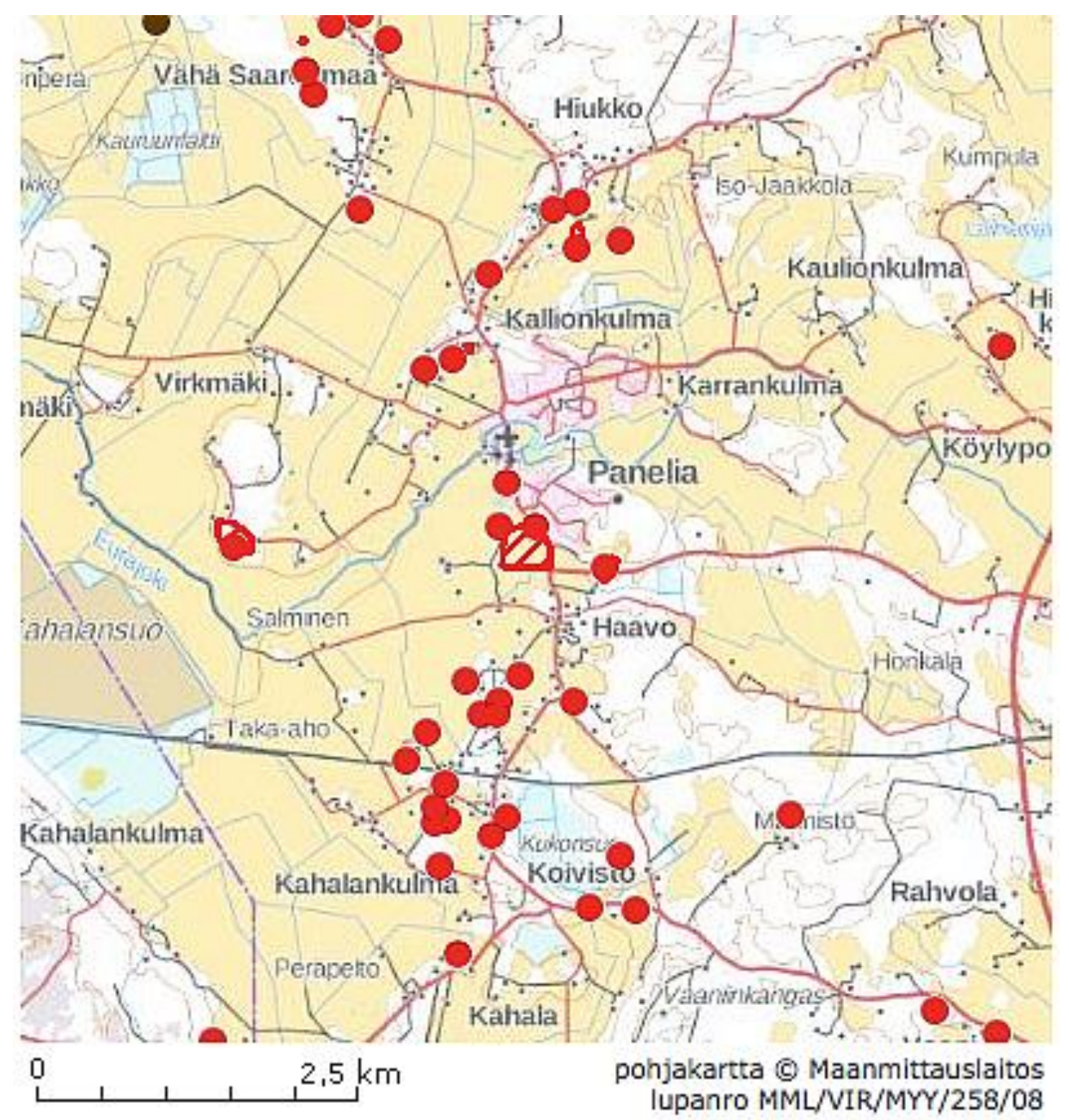

Fig 8. Map presenting the objects in Panelia area saved in Archaeological Heritage Database. Source: kulttuuriymparisto.nba.fi -> Eura

In the small village of Panelia (1,300 inhabitants) in Eura municipality, there are 37 valuable built heritage objects and 21 archaeological heritage objects. The village area is evaluated as Nationally Valuable Built Heritage area (RKY) and there is archaeologically valuable area surrounding Kuninkaanhauta archaeological site, which is the largest Bronze Age burial cairn in the Nordic countries. Despite of this expert recognition of deep and rich cultural landscape, none of these objects or areas were mentioned in the workshop. Participants (15) were 12 years old, covering all the children of this age in the village. The school has been active in heritage projects, one of them focusing on the Bronze Age in local landscape. Kuninkaanhauta site is by the main road, and other two larger cairns can almost be seen from the school yard. Participants pinpointed places similar to preceding workshops: Ice rink, play ground, shop windows, riding paths and home. Two places can be found also from the expert inventory: An old school building where three of the children started their school in the first class and a building from 1920's which is evaluated as important built heritage and is now functioning as pizzeria. Again, children do not pin-point objects found with with cultural heritage value framework, unless those objects are their homes, places of free time or related to some other activity.

Places in the largest categories, home and free-time, were reported in all the workshops, when other categories were more diversified. It is obvious, that the value of a child's home is intangible, 
and not generalized. These two categories coincide with the findings of Kyttä et al. about the scale of the reachable environment in diverse age groups amongst children. Free-time includes places of organized activities and places of hanging around, and they also mix, when children just hang out in a place designed for activities. Valuable places for children related to free-time are public places, where people run for errands, participate in free-time activities and go shopping. Such places are familiar from family routines, and children create their own space around those places as they grow up and enlarge the scale of independent moving. Sometimes the new way of using built heritage creates places, which afford cultural landscape values for children, too. This is the case in Friitala, where an old leather factory is turned into a commercial and sports use. More often the category of free-time is found from modern places like a mall, a shop window, a playground or a place of performance for sports. These places do not possess such values, which are defined in the Built Heritage Act or some other document used for expert inventories. Therefore the most of the places reported here in the significant category of free-time do not exist in those inventories. This coincides with the findings of Kaltenborn\&Bjerke (2010) about the place attachment and perceptions.

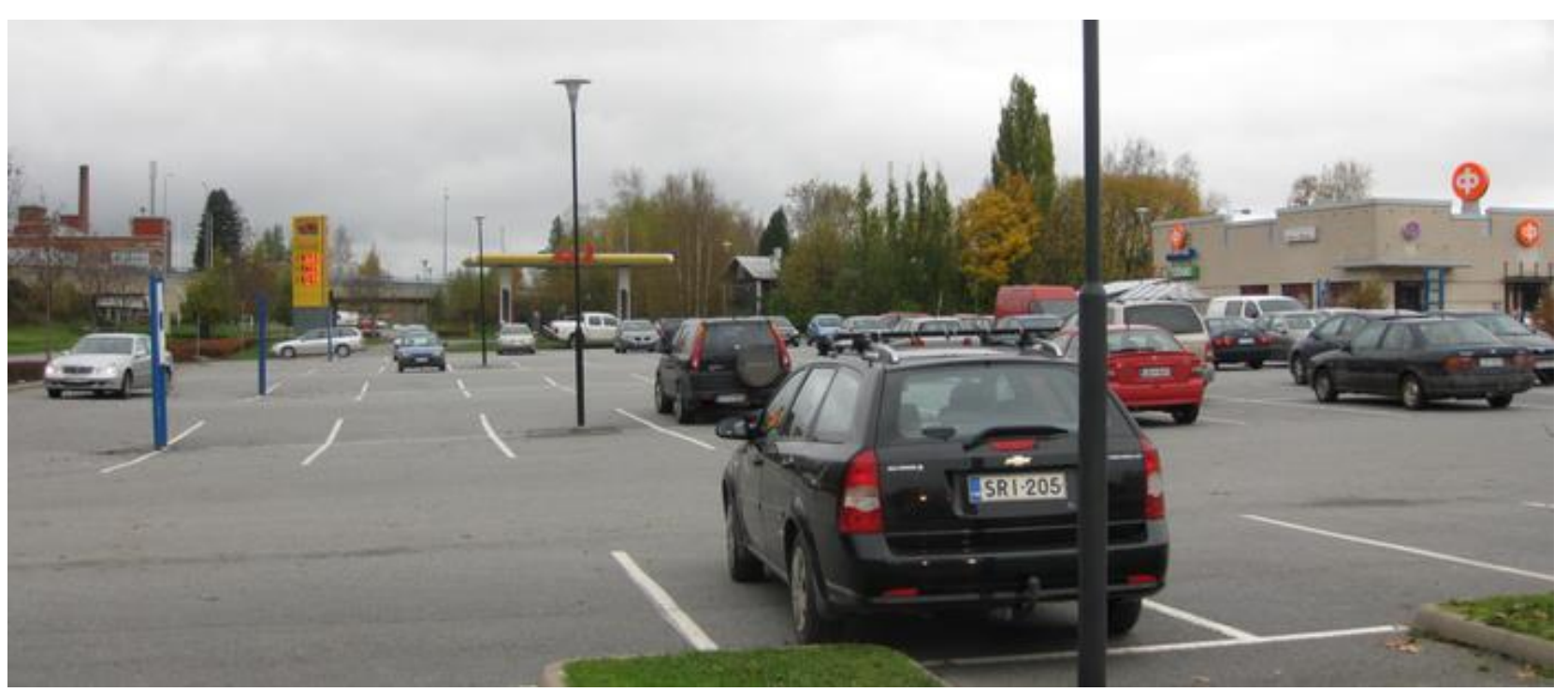

Fig 9. A mall in the center of Friitala village, Ulvila. Architecture is characteristic for the 1990's when shops, banks and other commercial services built joint premises usually to former agriculture land in urban fringe and bigger countryside villages. This place was mentioned frequently among pupils from Friitala school as a place of free time. Behind the mall, between gas station and road, is the oldest building in Friitala. It is a former main building of the blacksmith's farm of Swedish Royal Dragoon Regiment, which was stationed in Ulvila in the $18^{\text {th }}$ century. This valuable object of built heritage was totally unknown among children and their teachers, too. Classes visited it during the second phase of the workshops. Photo: Puolamäki, L.

Category of cultural heritage was reported only at Kaasmarkku and Rauma. In Kaasmarkku it was pin-pointed ( 3 of 13 pupils) at an old stone bridge, which has been restored by the village residents. It is quite clear, that the long tradition of the volunteer cultural landscape maintenance influences to children's opinions about and attitudes to their cultural landscape. They find places of valuable cultural heritage attractive, and they have gained a lot of knowledge about it.

"Bridge is important because it takes me to the river where I go to swim. It is also very beautiful. Once it was closed but people from my village restored it and now we can use it again"

Kaasmarkku school, $7^{\text {th }}$ October 2011. Girl, 10 years.

In Rauma, cultural heritage was pin-pointed to the World Heritage Site as an area (5 of 68 pupils). The World Heritage Site was pin-pointed twice as a place in free time category because of a familiar restaurant of family dinners and once as a point of interest because of a computer game called Clash of Clans. In that game churches are places of power lines; therefore the Church of the Holy Cross was pin-pointed by an 11-year old boy. Otherwise World Heritage was not visible in the children's evaluations. 


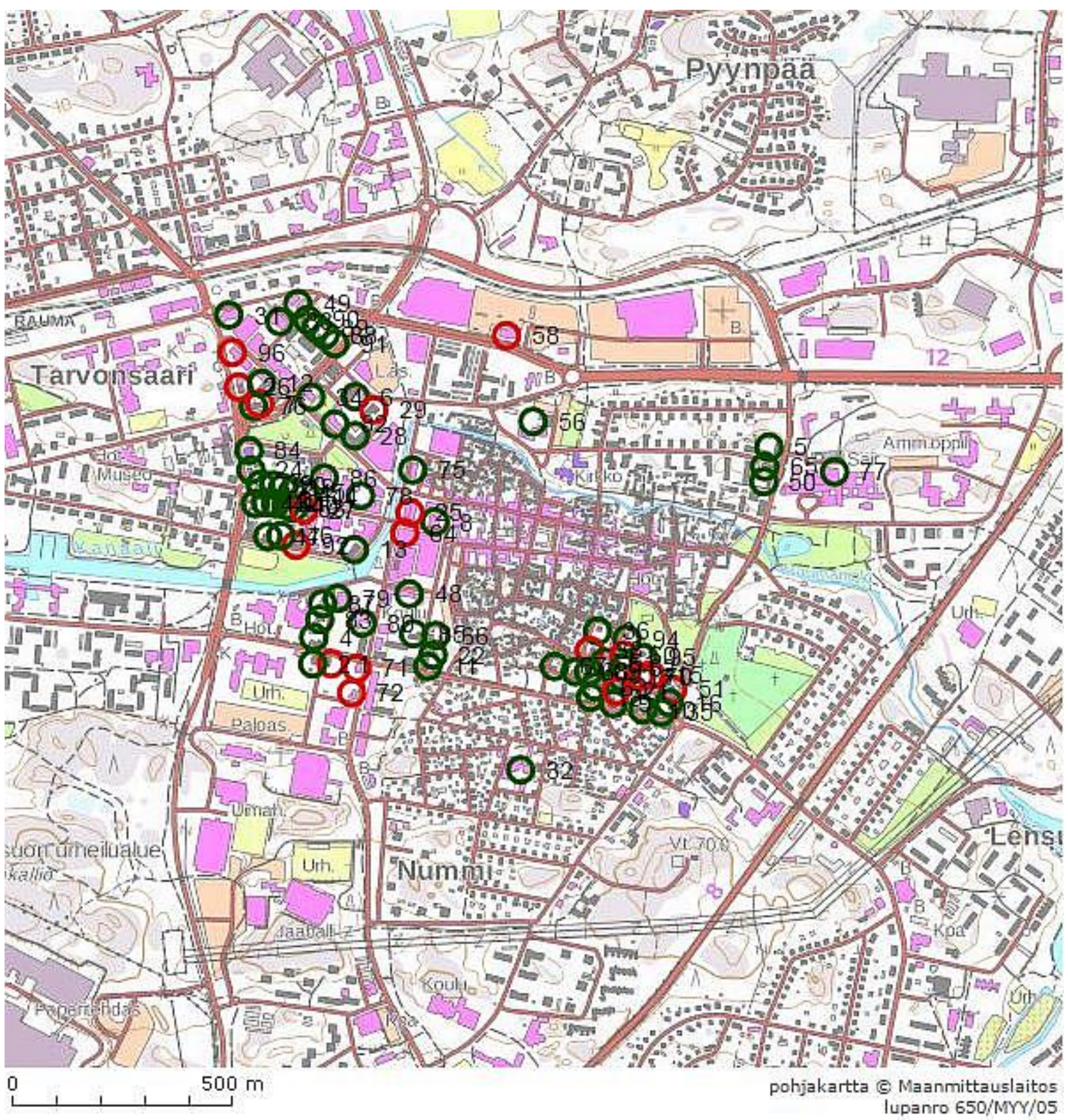

Fig 10. Old Rauma (Vanha Rauma) World Heritage Site has a buffer zone, where regulations are tighter than in other town areas. Built Heritage Inventory (Satakunta Museum) evaluated 71 valuable buildings in buffer zone. Source: Inventory database Pakki 


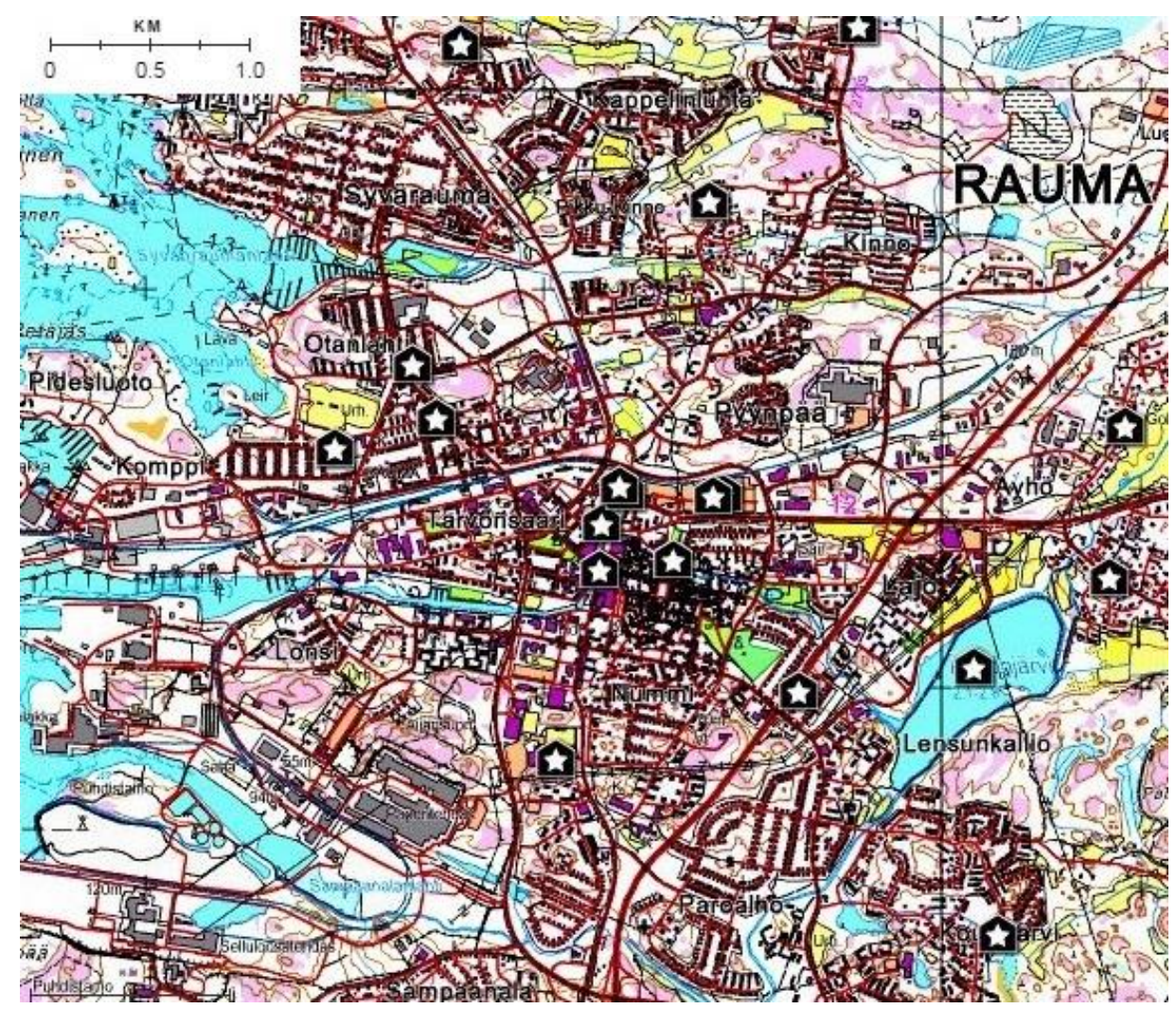

Fig 11. Workshops 1 and 2 in Rauma pin-pointed places from categories home, free-time, cultural heritage, commerce and school. Source: Paikkaoppi

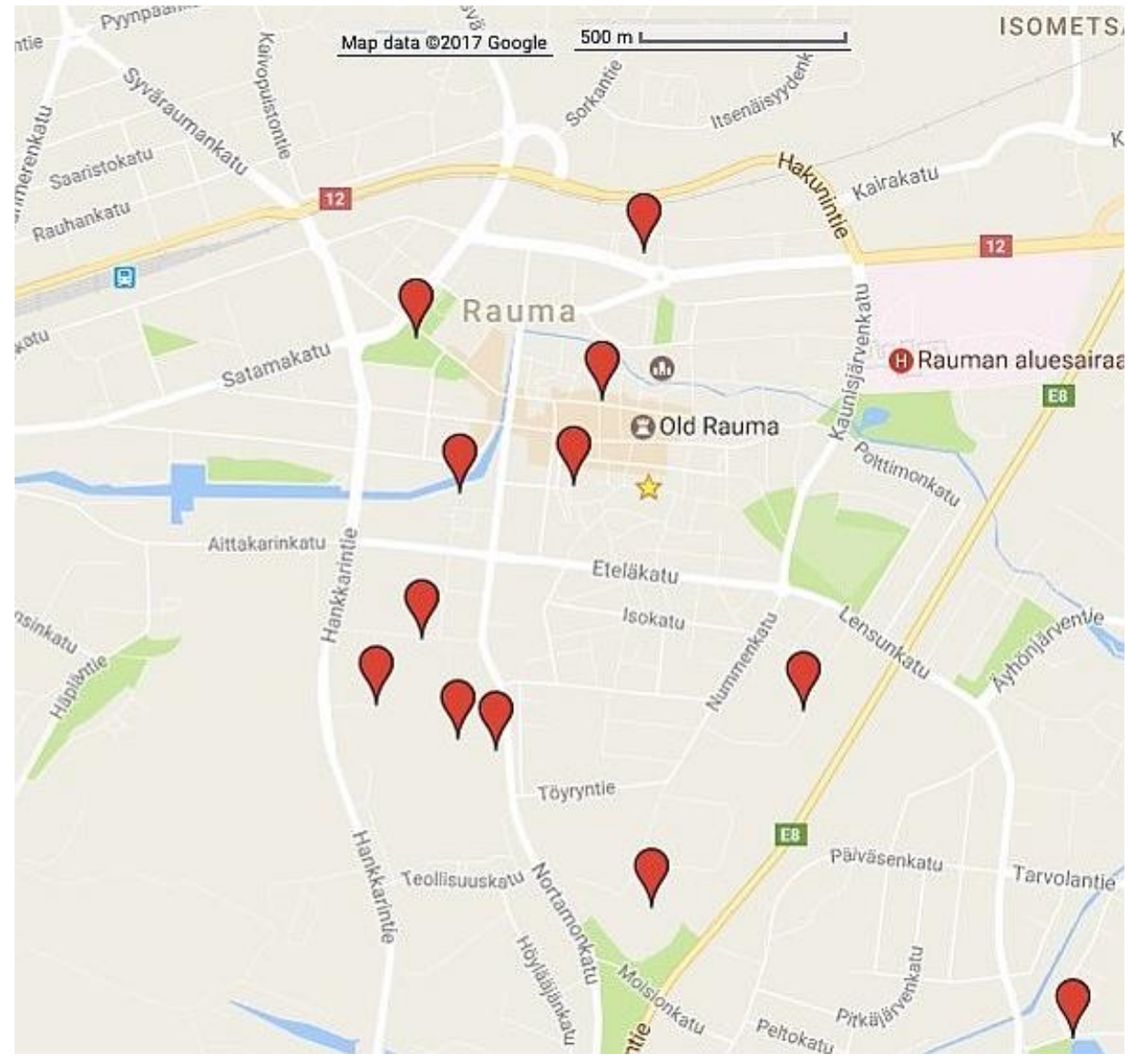

Fig 12. Workshop 3 in Rauma used Google Maps as a platform because Paikkaoppi was temporarily out of use in workshop day. Source: Google Maps 
Finland has seven World Heritage Sites. Old Rauma is the only site in a functional town centre. Town planning in the area is steered with World Heritage Convention and the Outstanding Universal Values recognized in the area. Planning architects and many municipal officers from cultural and administrative sectors interact with international partners from other World Heritage Sites. ICOMOS Finland and National Bureau of Antiquities are represented in Old Rauma management board. Despite this global interest, local children evaluate their town as mundane environment, detached from intergovernmental frameworks.

Gender is not a key factor in these cultural landscape evaluations; all the categories were reported by both genders.

Findings from the workshops of this study can be described through Brofenbrenner's (1979) concept of ecological human development and Krogh's model (Krogh et al., 2008: 22). Children are active explorers in the landscape. During their expeditions, even if it is only a way to the school and back, they make new landscape perceptions and reshape their landscape values with cognition. The further actions are built on previous cycle of perception, cognition and action, with reflection to their context in the cultural and social framework.

This framework is ever changing, because of the increased landscape competence of the children as they grow, enlarge their habitat, and develop their social network and environmental knowledge. Along with this process the cultural landscape is reshaped, as Krogh et al. describe it. Based on this study, it can be concluded, that children create an innate connection to the natural, cultural and social dynamics of the cultural landscape through experience. They perceive the landscape as a whole, not as fragments or specified elements of natural and cultural factors. But their practical knowledge about the landscape is also represented and codified in a way uncongenial to science, like the practical knowledge of the farmers in Argyll (Syse 2012). Additionally, it is challenging to include into the scientific or the expert documentation.

In the sustainable development context the cultural landscape values of children represent the dimensions of social and cultural sustainability. Their values interact with the cultural landscape through personal actions and landscape dynamics. Different age groups have been acknowledged in many sectors of the society, like education, health care, culture and sports. In the environmental sector, including cultural landscape issues, the role of the children is often to receive guidance and teachings about the environment, but not so much to express their own knowledge and perceptions about it.

Land use and Building Act is the main steering document of land use planning in cultural landscapes in Finland, if we exclude World Heritage Convention. It says that

"The objective of this Act is to ensure that the use of land and water areas and building activities on them create preconditions for a favorable living environment and promote ecologically, economically, socially and culturally sustainable development.

The Act also aims to ensure that everyone has the right to participate in the preparation process, and that planning is high quality and interactive, that expertise is comprehensive and that there is open provision of information on matters being processed."

Land Use and Building Act, Chapter One, Section One.

This case study showed that experts' cultural landscape evaluation process, based on this Act, is not optimized for fulfilling its objectives of promoting socially and culturally sustainable development at the moment. The parallel levels of valuable cultural landscapes overlap in some places occasionally through function, but more often they are separate and invisible to each other.

This case study showed also that working with children and cultural landscape values is productive and important but also time consuming. The interpretation of data is vulnerable to misunderstandings. Therefore it is vital that the researcher who analyzes the data participates in collecting it, being able to perceive the process and verify the results as well as the accuracy of the pin-pointed places or objects in the workshop. Some ice-breaking may also be needed to reach open and safe atmosphere. 


\section{Conclusion}

The starting point of this study was to find out where children's values are attached in the landscape of Satakunta Region, how they intertwine with expert values and how combining these diverse perspectives could contribute to preservation.

According to these results, children value places, which they are free to explore individually, in a group or with family. The valued places shift with growing environmental experience and knowledge and create a constantly reshaped evaluation framework. Experts frame the cultural landscape differently from children; the framework of the experts is stabilized, authorized and unified in governmental acts, strategies and reports. Observing the cultural landscape through these diverse frameworks creates casual similarities in places, but the values, which lie beneath the pin-pointing, are different.

Merging the different frameworks of children and adult experts in the cultural landscape evaluation requires broadening of the authority in cultural landscape. When the nationally and regionally valuable cultural landscape framework is brought into the local level, the local people of all ages need to be authorized to bring their knowledge into the evaluation process. The process is a place of social learning for these diverse experts, landscape professionals as well as local people, including children. A good starting point for cultural landscape evaluation in local level with these new authorities could be the notion of the landscape in the European Landscape Convention (CoE 2006). It defines landscape as

"an area as perceived by people".

This definition includes all the layers in the landscape, despite their historical depth or conclusive value. It includes the intangible landscape values as well. With this definition, these diverse, commensurable values cumulated in some places through different value frameworks could be turned into an asset in conservation.

The network of places pin-pointed by children and value categories extracted from them express the cultural landscape as an area as perceived by children. In the spirit of the European Landscape Convention, it should be accepted as such, equally with other layers expressed by other stakeholder or expert groups, although it would point to values or places excluded from listed objects or areas.

It also expresses the possibilities of engaging this group into conservation. Cultural planning combined with PGIS applications seem to be a considerable tool for identifying and locating diverse landscape values and their connections and diverse groups participation to bring their knowledge in with the skills they possess.

From the connectivity approach, the children's values in the cultural landscape are somewhat disconnected from the listed heritage values. This disconnection makes cultural landscape vulnerable for fragmentation in future changes.

Ecological landscape management and protection pursues to open and to connect the landscape for diverse species with corridors between patterns. Cultural landscape management and protection should perhaps apply the connectivity method as well.

Landscape evaluation produced with children by suitable methods reveal the network of places and ways to experience them. Experience is a key for opening cultural heritage to this group. By finding a way to afford the experience, their desire in the places of listed heritage could create a "corridor" for connecting children better to these objects and areas. And on the contrary, affording scientific knowledge of the places which children find valuable could connect other groups and scientific or local knowledge better with children's layer in the landscape. Disciplinary approaches and methods for introducing this can be found from the environmental education field.

Children and youth are comfortable with using social media applications when expressing themselves; this offers a possibility to develop new ways to engage with cultural heritage and landscape. Children can be participants in this process with the skills they possess; by introducing ways to experience cultural heritage and landscape, sharing knowledge about it and recording their perceptions. It offers also a way to collaborate efforts between different age- and stakeholder 
groups and experts in preservation. This process could enrich expertise of all kind, open up possibilities for new resources in preservation and bring us closer to the sustainable and resilient cultural landscape.

\section{Acknowledgements}

This research has received funding from the Finnish Cultural Foundation / Satakunta Regional Fund, Satakunnan Korkeakoulusäätiö and University of Turku, Degree Program in Cultural Production and Landscape Studies. I am grateful to Maunu Häyrynen, Simo Laakkonen and Riina Haanpää for providing feedback of an earlier version of the manuscript.

\section{Academic references}

[1] Bianchini, F. \& Ghilardi, L. (2007). Thinking culturally about place. Place Branding and Public Diplomacy. 3(4), 280-286. DOI: 10.1057/palgrave.pb.6000077.

[2] Bieling, C. \& Plieninger, T. (2012). Recording Manifestations of Cultural Ecosystem Services in the Landscape. Landscape Research 38(5), 649-667. DOI: 10.1080/01426397.2012.691469.

[3] Brofenbrenner, U. (1979). The Ecology of Human Development. Experiments by nature and Design. Cambridge: Harvard University Press.

[4] Brown, J. \& Mitchell, B. (2000). Landscape Stewardship: New directions in conservation of nature and culture. The Georg Wright Forum 17(1), 70-79.

[5] Brown, G. \& Reed, P. (2011). Social landscape Metrics: measures for Understanding Place Values from Public Participating Geographic Information Systems (PPGIS). Landscape Research 37(1), 73-90. DOI: 10.1080/01426397.2011.591487.

[6] Brunetta, G. \& Voghera, A. (2008). Evaluating Landscape for Shared values: Tools, Principles and Methods. Landscape Research 33(1), 71-87. DOI: 10.1080/01426390701773839.

[7] Crawhill, N. (2007). The role of participatory cultural mapping in promoting intercultural dialogue - 'We are not hyenas'. Paris: UNESCO. Retrieved from (http://portal.unesco.org/culture/en/files/37746/12197593145The_role_of_participatory_cult ural_mapping_in_promoting_intercultural_dialogue.pdf/The\%2Brole\%2Bof\%2Bparticipatory \%2Bcultural\%2Bmapping\%2Bin\%2Bpromoting\%2Bintercultural\%2Bdialogue.pdf (Accessed 23.3.2016).

[8] Duxbury, N., Jeannotte, M. S., eds. (2015). Cultural mapping in planning and development contexts. Culture and Local Governance 5(special issue 1-2).

[9] Fagerholm, N. \& Käyhkö, N. (2009). Participatory mapping and geographical patterns of the social landscape values of rural communities in Zanzibar, Tanzania. Fennia 187(1), 4360.

[10] Fagerholm. N., Käyhkö, N., Ndumbaro, F. \& Khamis, M. (2012). Community stakeholders' knowledge in landscape assessments - Mapping indicators for landscape services. Ecological Indicators 18, 421-433. DOI: 10.1016/j.ecolind.2011.12.004.

[11] Haapala, A. (2000). Luonnon kauneus ja rumuus. In Haapala, A. \& Oksanen, M., eds., Arvot ja luonnon arvottaminen (pp. 68-81). Helsinki: Gaudeamus.

[12] Hart, R. (1979). Children's experience of place. Sydney: Halsted Press.

[13] Innamaa, K. (1968). Suur-Ulvilan historia II. Pori: Satakunnan Kirjateolisuus Oy.

[14] Jones, M., Howard, P., Olwig, K. R., Primdahl, J. \& Sarlöv Herlin, I. (2007). Multiple interfaces of the European Landscape Convention. Norsk Geografisk Tidsskrift - Norwegian Journal of Geography, 61(4), 207-216. DOI: 10.1080/0029195070170917. 
[15] Jones, M. \& Stenseke, M. (2011). The European Landscape Convention. Challenges of Participation. New York: Springer.

[16] Kaltenborn, B. P. \& Bjerke ,T. (2002). Associations between Landscape Preferences and Place Attachment: A study in Røros, Southern Norway. Landscape Research 27(4), 381396. DOI: $10.1080 / 0142639022000023943$.

[17] Kirchhoff, T., Brand, F. S. \& Hoheisel, D. (2012). From cultural landscapes to resilient socialecological systems. In Plieninger, T. \& Bieling, C., eds., Resilience and the Cultural Landscape. Understanding and Managing Change in Human-Shaped Environments (pp. 4964). Cambridge University Press. DOI: 10.1017/CBO9781139107778.005.

[18] Kohonen, K. \& Tiala, T. (2002). Kuntalaiset ja hyvä osallisuus. Lupaavia käytäntöjä kuntalaisten osallistumis- ja vaikuttamismahdollisuuksien edistämiseksi. Helsinki: The Ministry of Internal Affairs.

[19] Korpela, K., Kyttä, M. \& Hartig, T. (2002). Restorative experience, self-regulation, and children's place preferences. Journal of Environmental Psychology 22(4), 387-398. DOI: 10.1006/jevp.2002.0277.

[20] Kyttä, M. (1997). Children's independent mobility in urban, small town, and rural environments. In Camstra, R., ed., Growing up in a changing urban landscape (pp. 41-52). Assen: Royal Van Gorcum.

[21] Kyttä, M. (2002). Affordances of children's environments in the context of cities, small towns, suburbs and rural villages in Finland and Belarus. Journal of Environmental Psychology 22(1-2), 109-123. DOI: 10.1006/jevp.2001.02.

[22] Kyttä, M. (2003). Children in Outdoor Contexts. Affordances and Independent Mobility in the Assessment of Environmental Child Friendliness. Espoo: Helsinki University of Technology.

[23] Mikusinski, G., Blicharka, M., Antonson, H., Henningsson, M., Göransson, G., Angelstam, P. \& Seiler, A. (2012). Integrating Ecological, Social and Cultural Dimensions in the Implementation of the Landscape Convention. Landscape Research 38(3), 384-393. DOI: 10.1080/01426397.2011.650629.

[24] Morrow, V. (2008). Ethical dilemmas in research with children and young people about their social environments. Children's geographies 6(1), 49-61. DOI: $10.1080 / 14733280701791918$.

[25] Pedersen, D. M. (1999). Dimensions of Environmental Competence. Journal of Environmental Psychology 19(3), 303-308. DOI: 10.1006/jevp.1999.0130.

[26] Plieninger, T. \& Bieling, C. (2012). Resilience and the Cultural Landscape. Understanding and Managing Change in Human-Shaped Environments. Cambridge University Press.

[27] Plieninger, T., Kizos, T., Bieling, C., Le Dû-Blayo, L., Budniok, M.-A., Bürgi, M., Crumley, C. L., Girod, G., Howard, P., Kolen, J., Kuemmerle, T., Milcinski, G., Palang, H., Trommler, K. \& Verburg, P. H. (2015). Exploring ecosystem-change and society through a landscape lens: recent progress in European landscape research. Ecology and Society 20(2), 5. DOI: 10.5751/ES-07443-200205.

[28] Poole, P. (2003). Cultural Mapping and Indigenous Peoples. A report for UNESCO.

[29] Puolamäki, L. (2012). Individual views and shared landscapes of folklore in Reykholtsdal, Iceland. European Countryside 4(2), 162-178. DOI: 10.2478/v10091-012-0021-8.

[30] Robin, L. (2012). Global Ideas in Local Places: The Humanities in Environmental management. Environmental Humanities 1, 69-84.

[31] Salo, U. (1981). Satakunnan pronssikausi 1, 2. The Regional Council of Satakunta.

[32] Salo, U. (2008). Ajan ammoisen oloista. Satakunnan ja naapurimaakuntien esihistoriaa. Helsinki: Suomalaisen Kirjallisuuden Seura. 
[33] Selman, P. (2006). Planning at the landscape Scale. London: Routledge.

[34] Selman, P. (2012). Sustainable Landscape Planning. The Reconnection Agenda. London: Routledge.

[35] Stewart, S. (2010). Cultural mapping toolkit. Retrieved from http://www.creativecity.ca/database/files/library/cultural_mapping_toolkit.pdf._Accessed 23.4.2015.

[36] Swensen, G., Jerpåsen, G. B., Saeter, O. \& Sundli Tveit, M. (2012). Capturing the Intangible and Tangible Aspects of Heritage: Personal versus Official Perspectives in Cultural Heritage management. Landscape Research 38(2), 203-221. DOI: 10.1080/0142397.2011.642346.

[37] Syse, K. V. L. (2010). Expert Systems, Local Knowledge and Power in Argyll, Scotland. Landscape Research 35(4), 469-484. DOI: 10.1080/01426397.2010.486855.

[38] Virkkala, K., Kopisto, A. \& Lehtinen, E. (1967). Suur-Ulvilan historia I: Pori: Satakunnan Kirjateollisuus.

[39] Wylie, J. (2007). Landscape. London: Routledge.

[40] Yli-Pelkonen, V. \& Kohl, J. (2005). The role of local ecological knowledge in sustainable urban planning: perspectives from Finland. Sustainability: science, practice, \& policy 1(1), 314.

\section{Other sources}

[41] Antiquities Act. 295/1963. finlex.fi.

[42] Built Heritage Act.4.6.2010/498. finlex.fi.

[43] Council of Europe (1985). Convention for the Protection of the Architectural Heritage of Europe (Granada Convention). [http://conventions.coe.int/Treaty/en/Treaties/Html/121.htm].

[44] Council of Europe (1992). European Convention on the Protection of the Archaeological Heritage (Revised, Valletta Convention).

[http://conventions.coe.int/Treaty/en/Treaties/Html/143.htm]

[45] Council of Europe (2000). European landscape convention. Council of Europe, Strasbourg, France. [online] URL:

http://www.coe.int/t/dg4/cultureheritage/heritage/Landscape/default_en.asp.

[46] Council of Europe (2005). Convention on the Value of Cultural Heritage for Society Faro Convention). [http://conventions.coe.int/Treaty/EN/Treaties/Html/199.htm]

[47] Krogh, E., Clemetsen, M., Bischoff, A., Jolly, L., Skår, M. \& Bjørnstad, K. (2008). Landscape - an Area as perceived by People. Paper submitted for the 23rd Session of PECSRL.

[48] Land Use and Building Act. 132/1999, amendment 222/2003 included. finlex.fi.

[49] Ministry of the Environment (1992). Important Landscape Areas [Report II of the working group on landscape areas]. Finnish Environment Institute Publications Archive. [http://hdl.handle.net/10138/29087]

[50] Nationally valuable landscapes. http://www.ymparisto.fi/enUS/Nature/Landscapes/Nationally_valuable_landscapes.

[51] Puolamäki, L. (2011-2012). Hesso, L. \& Helkiö-Mäkelä, H. \& Joukio, O. E-mail correspondence.

[52] Satakunta Museum. Inventory database Pakki. Satakunnan rakennusperintöselvitys 2005 (2007). In Lehto, S., ed., Satakuntalaiset kulttuuriympäristöt. The Regional Council of Satakunta. 
[53] UNESCO (1972). Convention Concerning the Protection of the World Cultural and Natural Heritage. [UNESCO.org » Culture » World Heritage Centre » About World Heritage » The Convention » Convention Text].

[54] UNESCO (2003). Convention for the Safeguarding of the Intangible Cultural Heritage. [UNESCO.org » Culture » Intangible Heritage » Convention » Text of the Convention].

[55] United Nations (1987). Our Common Future. Report of the World Commission on Environment and Development. [www.un-documents.net» Sustainable Development » Our Common Future].

[56] Valtakunnallisesti merkittävät rakennetut kulttuuriympäristöt RKY. National Bureau of Antiquities. RKY.fi. 